\title{
Belydenis in kerkregtelike verband met besondere verwysing na die konsep Kerkorde 1997, Neder- duitsch Hervormde Kerk van Afrika
}

\author{
S J Botha \\ Departement Kerkgeskiedenis (Afd A) \\ Universiteit van Pretoria
}

\begin{abstract}
Confession in the context of ecclesiastical polity with special reference to the concept Church Ordinance 1997, Nederduitsch Hervormde Kerk van Afrika

In essence the question under discussion is about the functioning of the confession in church polity and how it is phrased in the concept Church Ordinance (1997) of the Nederduitsch Hervormde Kerk van Afrika. This logically brings the very difficult question of doctrinal discipline up for discussion. The paper starts with a few remarks on the relation between scripture, confession and church polity. The tradition, forming the background of the concept, is traced from the time of the Reformation. After a short discussion on how doctrinal discipline was seen and put into practice in the Nederduitsch Hervormde Kerk van Afrika, final remarks are made on how this matter is handled in the concept.
\end{abstract}

\section{INLEIDING}

Die vraag wat hier aan die orde gestel word, bly "'n vraag wat telkens weer opduik met 'n meerdere of mindere mate van dringendheid' (Pont 1985:519). 'n Kort ekskurs in slegs die Hervormde Teologiese Studies sedert 1980 bring die waarheid van hierdie stelling duidelik aan die lig (vgl bv die volgende uitgawes: jrg 37/3; jrg 38/2 \& 3; jrg $41 / 3 \&$ jrg 41/4). Dit lyk egter tans nodig om opnuut aan die vraag aandag te gee in die lig van gebeure tydens en na die Nederduitsch Hervormde Kerkse vier-een-sestigste Algemene Kerkvergadering van 1995 (vgl verskillende uitgawes van Die Hervormer, September tot Desember 1995).

Wesenlik gaan dit hier om 'n kerkordelike vraag, soos die verwysing na die nuwe konsep Kerkorde duidelik impliseer. Die konsep Kerkorde wat hier ter sprake is, is die (finale) konsep wat voor die buitengewone Algemene Kerkvergadering van Junie-Julie 1997 gedien het (Agenda vir die buitengewone sitting van die vier en sestigste Algemene Kerkvergadering Junie-Julie 1997). Die vraag wat dus hier aan die orde gestel moet word, is die vraag na die funksie van die belydenis in die kerklike orde en hoe dit 
in die konsep Kerkorde verwoord is. Dit bring vanselfsprekend die ernstige aangeleentheid van leertug aan die orde en dit is nie so 'n eenvoudige en maklik afhandelbare saak nie. Tog is dit 'n saak wat nie deur die Hervormde Kerk vermy of omseil kan word nie.

As Van Ruler (1973:103) die vraag oorweeg: 'Hoe wordt de belijdenis in de leertucht gehandhaafd'? dan maak hy 'n paar opmerkings wat hier uiters ter sake is. Hy stel: 'Aan leertucht zal een kerk niet kunnen ontkomen. Daarvoor spreekt de Heilige Geest te duidelijk in de Heilige Schrift. Maar men moet wel bedenken, welke hoge dingen de Here God zijn kerk toeschikt en van haar verwacht, als Hij haar de taak opdracht, leertucht uit te oefen'.

Om hiedie ontsaglike en mensliker wyse gesproke onmoontlike verantwoordelikheid tog te kan uitvoer, doen Van Ruler aan die hand dat dit altyd gedoen sal word onder drie gesigspunte:

* Die hele waarheid van God sal voortdurend in aanmerking geneem moet word. Die belydenis moet wel as meetlat gebruik word, maar dan in lewende verband met die totale Skrifgetuienis, met die totale belydenis van die vadere, sowel ekumenies as gereformeerd, en met die gehele aktuele situasie van die huidige belydende kerk. Die belydenis of gedeelte van die belydenis sal eers weer opnuut as waarheid vasgestel moet word. As 'n afwyking dan getug word, sal die sekerheid moet bestaan dat dit die totale waarheid van God sou kon bederf (Van Ruler 1973:103).

* Daar moet sekerheid bestaan dat die een wat deur die leertug getref word, inderdaad 'Gods gang met zijn kerk in de geschiedenis van de wereld tegenstaat'. Hy maak dan 'n onderskeid tussen die empiriese en etiese ketter wat miskien vertaal kan word as die openlike en ondergrondse ketter. Dit moet, soos hy dit stel, 'pneumatisch noodzakelijk' wees voordat 'n ketter verwyder word (Van Ruler 1973:104).

* By (leer)tug moet duidelik in die oog gehou word dat dit wesenlik gaan om die hantering van die sleutels van die hemelryk (Van Ruler 1973:104).

Van Ruler het nie in gedagte dat in die praktyk van die leertug dit maar net moet gaan om die blote toepassing van hierdie drie abstrakte gesigspunte nie. Waarop hy hier die klem wil lê is '... de reinheid en de heiligheid van de kerk staan op het spel in de leertucht, en dat veral ook in de wijze, waarop deze wordt uitgeoefend'. 
Dit is dus nie net noodsaaklik dat leertug toegepas moet word nie maar ook hoe dit uitgeoefen word, is van die grootste belang. Dit kom daarop neer dat leertug wat op 'n onregmatige en onbehoorlike wyse toegepas word, net so skadelik vir die kerk kan wees as die kettery wat teengestaan word. Daarom waarsku hy diegene wat geroep is om aan 'n leertugprosedure deel te neem, sowel as diegene wat belangstellend daaromheen staan en kyk, om noukeurig in gedagte te hou watter geweldige en feitlik onmoontlike verantwoordelikheid hier aan die kerk opgedra is. Die wat aan die prosedure deelneem, moet 'n duidelike besef hê waarmee hulle besig is en die wat toekyk:

moet niet al te hard (te) roepen vóór of tégen de leertucht (in het algemeen of in concrete gevallen), maar in zekere ontzetting, althans in vrees en beving (te) bedenken, hoe ongehoord zwaar het is, kerk van de levende God te zijn in deze wereld, zoals zij is, daarin zijn naam te belijden en deze belijdenis daadwerkelijk te handhaven.

(Van Ruler 1973:104)

Ook Berkouwer verklaar onomwonde dat leertug 'allerminst een simpele aangelegenheid' is waar ook voortdurend tweërlei gevaar dreig naamlik enersyds 'indifferentisme en grenzelose tolerantie' en andersyds 'n ontaarding in ketterjagtery (Berkhouwer 1972: 209).

Dit kan seker net verstandig wees om by eie kerkordelike reëlings en optrede rondom belydenis en (leer)tug, rekening te hou met hierdie gewigtige en waarskuwende woorde van Van Ruler en Berkouwer.

\section{BELYDENIS EN KERKORDE}

In die presbiteriaal-sinodale kerkbegrip moet daar 'n onverbreekbare verhouding wees tussen Skrif, belydenisskrif en kerkorde. Trouens Skrif-belydenisskrif-kerkorde moet in mekaar se verlengde lê, maar dan moet ook duidelik begryp word dat daar ' $n$ besliste en onomkeerbare rangorde is, naamlik dat die Skrif die norma normans, die belydenis die norma normata en die kerkorde die struktuur of uiterlike dop van die gehoorsaamheid aan Skrif en belydenis is (vgl Van Wyk 1991:22vv; Coertzen 1991:177-183; Botha 1993:7). Die belydenis is dus wel deeglik belangrik by die ordening van die struktuur van die kerk. Saam met Velthuysen (1985) kan die belydenis een van die vier konstituerende elemente in die kerklike struktuur genoem word. Die ander drie wat hy noem, is die teologie, die verkondiging en die kerkorde. Hy beskou die belydenis egter as die belangrikste bousteen in die struktuur van die kerk en sê dan verder oor die belydenis: 
Dit is immers aanduidend van die aard en karakter, van die 'persoonlikheid' van die kerk. Dit is die middel waardeur die kerk hom afgrens van die nie-kerk en valse kerk. Dit is die instrument waarmee hy hom voor die wêreld en ander kerke verantwoord. Dit is uiteindelik die aanduiding van die wyse waarop die kerk op sy fondament gebou is, asook van die ingange waarlangs die Woord in die kerk inspraak het. Juis om hierdie rede is die belydenis die voorwaarde vir orde en geordendheid binne die kerklike struktuur. Dit dui grense aan. Dit trek riglyne. Dit dui die breë beginselraamwerk aan waarbinne die kerk homself verstaan, asook die breë lyne waarlangs hy sy optrede in die wêreld wil loods.

(Velthuysen 1985:373)

Dit is dus baie duidelik dat die belydenis vir die kerk en vir die kerklike struktuur onontbeerlik is. Daarom is dit vanselfsprekend dat ' $n$ kerk in sy kerkorde bepalings sal hê in verband met sy belydenis. Trouens, tereg sê Velthuysen dat daar 'n ambivalente verhouding tussen die belydenis en die kerkorde bestaan. Dit blyk daaruit dat die kerkorde gebou is op die belydenis, terwyl hy hom weer in die kerkorde verbind aan die belydenis. Hierdie verbintenis aan die belydenis is van kardinale belang, "want dit is ineens die waarborg daarvoor dat daar werklik orde sal wees, orde op 'n vaste basis en nie volgens arbitrêre insigte nie' (Velthuysen 1985:375).

Op hierdie punt is dit ook van belang om nog twee opmerkings te maak:

* Die kerk het die belydenis slegs uitgedruk of verwoord in die belydenisskrifte. Hieruit volg logies dat ' $n$ belydenisskrif die skriftelike neerslag is van 'n belydenis wat eksistensiële geloof in Christus uitdruk en nie self 'n belydenis is nie (Pont 1985:524). Hieruit volg weer dat die belydenisskrifte nie in die plek van of gelyk aan die Heilige Skrif gestel kan word nie. Tog is die belydenisskrifte vir die kerk baie belangrik omdat dit niks anders wil sê as wat die Heilige Skrif self sê nie. Pont (1985:524) konkludeer dan: 'As die Skrif, die skriftelik gefikseerde Woord van God, die regula fidei vir die gelowiges is, dan is die belydenisskrif niks anders nie as die kort, in mens-woorde saamgevatte essensie van die regula fidei'. Natuurlik is die belydenisskrif sekondêr ten opsigte van die Skrif en as mensewoord tydelik en altyd hersienbaar aan die hand van die Heilige Skrif. Dit spreek egter ook vanself dat by die hersiening van 'n belydenisskrif die kerk in sy orde 'n ordelike weg sal voorskryf. Juis by die voorskrifte is dit noodsaaklik om Van Ruler se waarskuwings en opmerkings in gedagte te hou. 
* Dit is ook belangrik om daarop te let dat in die konsep Kerkorde, net soos in die tans bestaande en geldende Kerkwet en Bepalings die begrip leer gebruik word as 'n wisselvorm vir die begrip belydenis (vgl konsep Kerkorde: Ordereël 1.1. \& Kerkwet en Bepalings 1995: bepaling 73).

\section{ENKELE HISTORIESE OPMERKINGS}

In die Nederduitsch Hervormde Kerk is nog altyd ook teruggegryp na sy eie kerkordelike tradisie as ' $n$ bron by die vasstelling van kerkordelike reëls (Coertzen 1991:117149). Dit is nog altyd gedoen onder die uitdruklike voorwaarde dat dit nie in stryd mag wees met Skrif en belydenis nie.

Om by die oorsprong van die tradisie uit te kom, moet teruggegaan word tot by die Kerkhervorming van die sestiende eeu en dan meer in die besonder tot by die hervormingswerk van Johannes Calvyn (vgl Botha 1980:1-5; Botha 1981:30-33 \& Pont 1981:6-14). Die Kerkhervorming het 'n aanmerklike uitbreiding van die belydenisskat van die kerk gebring. Dit is nogal merkwaardig aangesien die Reformatore, en dan veral Calvyn, voortdurend gemaan het dat nie ligtelik nuwe belydenisse opgestel moes word nie (Plomp 1969:246). Dit was die nood van bepaalde omstandighede wat tot die opstel van belydenisse gelei het. Dit kon nie anders nie: die kerk is gedwing tot eksistensiële beslissings om sy geloof daadwerklik te bely (De Wet 1973:41). Omdat die kerk belydende kerk wou wees was die belydenisse nie bedoel om rasioneel en kunstig voorbereide dokumente te wees nie, maar wel om die geloof van die kerk tot uitdrukking te bring.

By al die Reformatore het dit vasgestaan dat die kerklike belydenis antwoord moes wees op God se Woord soos dit in die Skrif gegee is en niks meer nie. Die Skrif alleen het steeds as die enigste norm gegeld van wat die kerk mag glo en leer. Die belydenis, wat bedoel het om die inhoud van die Skrif saam te vat en so te bely wat die Skrif oor bepaalde sake leer, was mensewoord en kon daarom nooit bo of selfs gelyk met die Skrif as God se Woord gestel word nie. Die belydenis was ondergeskik en voortdurend toetsbaar aan die Skrif.

Tog het die Reformatore geoordeel dat die kerklike belydenisse wel daadwerklike gesag gehad het (Pont 1981:239-240; Bouwman 1912:187). In die verband het hulle egter twee vereistes gestel, naamlik dat dit volgens of ooreenkomstig God se Woord moes wees en dat dit deur 'n gesaghebbende kerklike vergadering aanvaar moes wees. Die Skrif was inderdaad die norma normans of regula fidei met goddelike en daarom met absolute gesag. Die kerklike belydenis daarenteen is gesien as norma normata met betreklike, afgeleide en sekondêre gesag, 'n norma secondaria. Tog is geoordeel dat dit 'n gesag was wat deur almal in die kerk gehoorsaam moes word. 
Die Reformatore was oortuig dat onder die leiding van die Heilige Gees bepaalde waarhede uit die Skrif in die belydenis as waarhede van God saamgevat is en dat dit as belydenis geglo en gehandhaaf moes word op grond van God se Woord. Binne kerkregtelike verband het dit ingehou dat al die lidmate, en in die besonder die predikante, volkome met die kerklike belydenis sou instem. Van die predikante is in die besonder verwag dat hulle die belydenis sou onderteken as waarborg vir die regte uitoefening van hulle amp (Plomp 1969:257).

Die uitgangspunt dat die belydenisse wel gesag gehad het, bring vanselfsprekend die saak van leertug na vore. Daarom word vervolgens kortliks gekyk na die standpunte en houdings van die belangrikste Reformatore in verband met die tug in die algemeen en leertug in die besonder. Dit kan gestel word dat hulle dit eens was dat oor sowel die suiwerheid van die lewe as die suiwerheid van die leer van die kerk gewaak moes word. Dit was immers hulle hele bedoeling om die verworde kerk in sowel leer as lewe te hervorm met die klem veral op die leer. Hulle was oortuig dat die verbastering in die leer van die kerk, die oorsaak was van die totale verwording van die kerk. Om by die gesonde leer te bly sou daarom geskikte maatreëls getref moes word.

Hoewel Luther die regering van die kerk en daarmee ook die tug in praktyk aan die burgerlike owerheid oorgelaat het, het hy aan die ander kant daarop aangedring dat tugoefening in die kerk toegepas moes word (Bouwman 1912:62-69). Hy was van oordeel dat veral oor die verkondiger van die evangelie toesig moes wees en dat die Skrif alleen die maatstaf moes wees. Die tug moes volgens hom deur die gemeente self toegepas word en daarom was die gemeente '... nicht nur berechtigt, sondern verpflichtet, die Lehre des Predigers ständig zu prüfen, ob sie mit dem Wort Gottes übereinstimt. Wo das nicht der Fall ist, kann die Gemeinde ihren priester auch wieder absetzen' (Hovius 1968:11; Plomp 1969:56).

Onder druk van die bepaalde omstandighede in Zürich het Zwingli die tug uiteindelik ook in die hande van die burgerlike owerheid gelaat. Tog is dit van betekenis dat in 1528 in Zürich ' $n$ sinode ingestel is wat tweemaal per jaar vergader het om juis die leer en lewe van elke predikant volledig te bespreek. Die predikant kon hom dan self verantwoord of verandering beloof (Plomp 1969:56).

Johannes Calvyn was by uitstek die Hervormer wat die beginsel dat Christus self sy kerk regeer, konsekwent ontwikkel en in praktyk probeer bring het. Volgens hom kon die kerk nie werklik sonder die tug bestaan nie, daarom was die tug noodsaaklik en nuttig vir die kerk. Die instelling van die tug, wat die gemeente dien soos senuwees die liggaam, het hy teruggevoer na Christus self. In sy groot werk Institutio Christianae religionis het Calvyn sy siening van die kerklike tug uiteengesit en is verskeie kerkordelike reëlings van sy eie hand of van dié van sy volgelinge in praktyk 
uitgewerk. Hoewel Calvyn nie self die tug as derde merkteken van die ware kerk aangedui het nie, was sy uitsprake daaroor genoegsame rede vir sy navolgers om dit wel te doen. Plomp is van mening dat Calvyn wel op 'n baie subtiele wyse die onderskeid getref het dat die tug as merkteken nie tot die esse van die kerk nie, maar wel tot die bene esse van die kerk gereken moes word (Plomp 1968:127). Calvyn het aan die dienaars van die Woord besonder hoë eise gestel en betoog dat hulle onder strenger maatreëls as die ander lidmate gestaan het (Calvyn IV, 12, 22). Hulle was naamlik onderworpe aan sowel die communis disciplina, wat vir al die lidmate gegeld het, as die propria disciplina, wat in besonder op hulle betrekking gehad het. Ongelukkig het Calvyn nie besonder breedvoerig op die propria disciplinia ingegaan nie en sy betoog is ook eerder histories as prinsipieel. Wat die hoofsake betref, wou hy wel dat die praktyk van die vroeë kerk herstel word. Plomp vat hierdie hoofsake so saam: '... dat niemand tot het amp zal worden toegelaten dan na een nougezet onderzoek met betrekking tot zijn leer en leven en dat ook ná de ordinatie opzicht en tucht over levenswandel en ambtsbediening worden uitgeoefend' (Plomp 1969:253).

Interessant is dat Calvyn, anders as Luther, nie aan die lidmate besondere seggenskap toeken by die beoordeling van die geestelikes nie. Hy beskou dit in die eerste plek as ' $n$ verantwoordelikheid wat die dienaars van die Woord teenoor mekaar moet nakom. Die broederlike gemeenskap wat hulle aan mekaar bind, dring hulle daartoe om mekaar te vermaan. Maar dit mag nie beteken dat hulle mekaar se sondes wegsteek nie, maar eerder die teenoorgestelde: hulle moes baie strenger teenoor mekaar wees as teenoor die lidmate (Plomp 1969:253-254).

As die tug oor die leeramp behandel word, dan kom dié sake ter sprake wat Calvyn die potestas ecclesiae quoad fidei dogmata of kortweg potestas in doctrina noem. Dit kan weer in twee onderafdelings verdeel word naamlik die authoritas dogmatum tradentorum en die potestas in Scripturae interpretationis (Plomp 1969:255-259). Aan die eerste onderafdeling wy Calvyn beide hoofstukke 8 en 9 van boek IV. Plomp som die hooflyne van Calvyn se gedagtes, soos dit in die hoofstukke navore kom, soos volg op:

(a) Voor Woord van God mag niets anders worden gehouden dan de in het Oude en Nieuwe Testament geboekstaafde goddelijke openbaring. Dat Woord is de enige norm voor wat in de kerk mag worden geleerd

(b) De kerk is niet bevoegd tot het opstellen van nieuwe geloofsartikelen (novos fidei articolos) in de zin van leerstellingen die aan de Schrift iets nieuws zouden toevoegen. Wel heeft de kerk, door de omstandigheden daartoe genoopt, meermalen leeruitspraken gedaan, maar 
die bedoelen niets anders dan de oorspronkelijke bedoeling van de Schrift op eenvoudige wijze te verduideliken.

(c) Zulke leeruitspraken werden gedaan door concilies. Vooral de oude concilies verdienen hooglijk gewaardeerd te worden. Maar alle uitspraken van welke concilies ook, moet worden beschouwd als 'praeiudicia', voorlopige oordelen, die altyd opnieuw aan de regel van de Schrift getoetst moeten worden.

(d) De uiteenzetting loopt uit op een korte conclusie: aan de kerk is geen macht gegeven om een nieuwe leer in te voeren.

(Plomp 1969:256)

In die lig van die opskrif van hoofstuk 8 van boek IV naamlik kerklike mag sover dit die geloofsleer aangaan, lyk hierdie slotsom uiters negatief. Calvyn se hele betoog dra hier 'n baie sterk waarskuwende gedagte dat die kerk nie met die opstel van 'n geloofsbelydenis al te haastig moet wees nie, maar uiters versigtig en omsigtig. Daarmee het hy egter nie die opstel van geloofsartikels, as samevatting van die inhoud van die Skrif, prinsipieel afgewys nie. Hy was self betrokke by die opstel van geloofsbelydenisse en het ander aangemoedig om dit ook te doen. So was hy betrokke by die Instruction et Confession de Foy, 'n kategismus en geloofsbelydenis wat in 1537 in Genéve verskyn het en in 1559 het hy 'n konsep van 34 artikels aan die Sinode van Parys voorgelê wat met baie min wysigings en enkele byvoegings anvaar is as die Confessio Gallicana (De Greef 1989:133).

In Oktober 1548 het hy Eduard Seymore, die hertog van Somerset, geadviseer om selfs twee samevattings van die Christelike geloof op te stel (Plomp 1969:257). In 'n redelik uitvoerige skrywe aan Somerset het Calvyn belangrike uitsprake gemaak waaruit sy standpunt ten op sigte van die kerklike belydenisskrifte duideliker navore kom. Eerstens is dit duidelik dat hy steeds by sy reeds bekende standpunt bly dat die Woord van God soos dit in die Heilige Skrif gegee is, die regula fidei is. Die leer van Christus word primêr in die Heilige Skrif gevind, maar tog kon die kerklike belydenisskrif gesien word as 'n samevatting van dié leer. Veral wanneer dwaalleer en ligsinnigheid van vrydenkende geeste aan bande gelê moes word, was die belydenisskrif van besondere waarde. Calvyn noem dit dan 'n goeie en beproefde middel wat God self aandui. Calvyn stel dit so: 
Dit is, eerstens, dat daar 'n samevatting van die leer moet wees wat almal moet verkondig. Alle kerklike ampsdraers en predikante moet onder eed verklaar dat hulle hierdie belydenis sal onderhou en niemand moet tot ' $n$ kerklike amp toegelaat word wat nie belowe het om hom aan hierdie afspraak te hou nie.

Verder is 'n gemeenskaplike leerboek vir die kinders en die ongeletterde volk nodig waardeur die goeie leer aan hulle toevertrou word sodat hulle self die leuens en weerleggings, wat miskien in teenstelling tot so 'n leerboek ingebring kan word, kan onderskei.

Hierdie Kategismus kan dus vir 'n dubbele doel nuttig wees, naamlik om die volk alles te leer sodat hulle die prediking kan benut en hulle ook kan onderskei wanneer een of ander eiesinnige mens ' $n$ vreemdsoortige leer voordra. Tog dink ek dat dit goed en selfs noodsaaklik is om die predikante te verplig om 'n bepaalde, skriftelike vorm van die leer te aanvaar sowel om die gebrek aan kennis en eenvormigheid by sommige te hulp te kom as om ook die ooreenstemming en eenheid van alle kerke beter tot uitdrukking te bring, en in die derde plek, om alle nuwighede en nuuskierigheid van predikante, wat alleen maar iets besonders na vore wil bring, in die kiem te smoor. Soos reeds gesê, vir derglike mense moet die kategismus as teuel dien.

(Vertaling van Pont 1982:12)

Samevattend kan gestel word dat vir Calvyn, soos vir die ander Reformatore, die Heilige Skrif die enigste, absolute norm was om vas te stel wat die ware leer is. Ook vir hom was die Heilige Skrif die enigste en primêre bron vir leer en lewe. Tog het hy die kerklike belydenisskrifte, as genormeerde norme gesien wat ook as maatstaf kon geld, omdat dit self aan die oordeel van die Skrif onderwerp was. Hierin het Calvyn nie verskil van die siening in die Lutherse kerke nie (Pont 1982:10). Calvyn het geweldig klem gelê op die suiwere verkondiging van die evangelie want vir hom was die viva vox evangelii die geestelike swaard van God se Woord. Juis daarom het die belydenisskrif, as die kerk se antwoord op God se Woord, ook 'n bepaalde funksie ten opsigte van die prediking gekry. Dit was naamlik om die verkondiging van dwaalleer in die kerk te voorkom (Pont 1982:12).

Wat Calvyn se oproep aan Somerset ten opsigte van die binding van die predikant aan die belydenis betref, het hy dit self reeds in die Ordonnances Ecclésiastique van Genéve van 1541 in artikel 7 so verwoord: 'Om elke gevaar te vermy dat die kandi- 
daat een of ander dwaalleer aanhang, sal van hom 'n belofte geëis word dat hy hom aan die leer, wat die kerk goedgekeur het, sal hou. Hier sal die inhoud van die Kategismus normatief wees (Pont 1981a:23). Die Kategismus waarna hier verwys word, was die Geneefse Instruction et Confession de Foy van 1537 en later.

Oor die tweede onderafdeling, naamlik die potestas in Scripturae interpretationis, handel Calvyn slegs in een paragraaf, naamlik boek IV, 9, 13. Hy stel dit onomwonde dat hy nie daaronder verstaan dat die kerk die bevoegdheid het om die Skrif goed te keur nie. Dit beskou hy as godslastering wat wel by Rome voorkom. Die mag of gesag wat die kerk wel het om die Skrif uit te lê, is vir Calvyn die bevoegdheid om leergeskille by te lê. Daar is volgens hom geen beter en betroubaarder geneesmiddel (nec melius nec remedium) om leerverskille op te los as 'n konsilie van regsinnige biskoppe wat oor die saak kan beslis nie (Plomp 1969:258). Aan die ander kant beteken dit nie dat hy alle uitsprake van konsilies sonder meer as vera et certa Scripturae interpretatio beskou nie. Die kerk het wel die belofte dat die Heilige Gees leiding sal skenk, maar dwaling is nie uitgesluit nie en hoër beroep op die Skrif is altyd gewettig. Die wyse waarop die Heilige Gees die kerk lei, is egter wel dié van die gesprek of gemeen-skaplike beraadslaging (Plomp 1969:259).

Besonder interessant is dit om daarop te let dat Calvyn na sekere leerstukke van die kerk as noodsaaklik (necessaria) verwys omdat hulle die eintlike leerstukke van die Christelike geloof (propria religionis placita) bevat. Hy noem as voorbeelde dat daar een God is, dat Christus God is en die Seun van God, en dat ons saligheid in die barmhartigheid van God geleë is. By hierdie hoofsake mag niemand 'n ander gedagte hê nie (Calvyn IV, 1, 12; vgl Plomp 1969:259). Ander leerstukke wat hy res non ita necessaria noem, is nie so belangrik dat verskil daaroor die eenheid van geloof en belydenis hoef te verskeur nie. Sulke kleiner verskille kan en moet daarom verdra word (Calvyn IV, 1, 12).

Voordat daartoe oorgegaan word om aandag te gee daaraan hoe Calvyn se gedagtes in Nederland neerslag gevind het, is dit terwille van volledigheid ook interessant om daarna te verwys dat iemand soos Zacharias Ursinus wel 'n teenstellende gedagte oor die belydenis daarop nagehou het. In Calvinistiese geledere het hy egter geen navolging gevind nie, hoewel Jacobus Arminus in sy stryd met Gomarus wel die standpunt van Ursinus met instemming aangehaal het (Pont 1981:13).

\section{DIE BELYDENIS IN DIE NEDERLANDSE HERVORMDE KERK}

Die gedagtes van Calvyn rondom die posisie van die belydenis in die kerk, is oral in Europa waar die Calvinistiese Reformasie deurgevoer is, ook in mindere of meerdere 
mate toegepas. Die Nederlandse Hervormde Kerk is hiervan ' $n$ voorbeeld, waar in beginsel en praktyk gepoog is om aan hierdie gedagtes van Calvyn gestalte te gee. In beginsel is dit verwoord in die Nederlandse Geloofsbelydenis (Art 29-32), die Heidelbergse Kategismus (vrg en antw 85), asook in verskeie kerkordes. Talle voorbeelde kan ook aangetoon word waar dit prakties toegepas is. Die beste voorbeeld van toepassing in die Nederlandse Kerk is sekerlik die groot Nasionale Sinode van Dordt 1618-1619, waar die Dordtse Leerreëls opgestel en leertug toegepas is. By die geleentheid is selfs meer as 200 predikante vanweë afwykende leerstellings afgesit (Bouwman 1912:126).

Reeds van vroeg af is in die Nederlandse Kerk van die predikante verwag om die belydenisskrifte van die Kerk te onderteken. Aanvanklik het dit slegs die bedoeling gehad om die eenheid in die leer tot uitdrukking te bring. Op die provinsiale sinode van Suid-Holland (1578) is vir die eerste keer 'n diepgaande debat gevoer oor die saak dat die ondertekening van die belydenisskrifte nie alleen geld om die eenheid in leer uit te druk nie, maar om ook die suiwerheid van die leer te bevestig. Terseldertyd is geargumenteer dat die klassikale vergadering die bevoegdheid moes hê om met 'n predikant te handel indien daar bedenkinge oor sy regsinnigheid sou ontstaan (Augustyn 1969:60-61). By die Nasionale Sinode van Dordrecht van 1586 word onder andere bepaal dat predikante wat sou weier om die belydenisskrifte te onderteken en daarin volhard, afgesit moet word (Pont 1981:18).

Geleidelik het daar as gevolg van die botsings op leerstellige gebied tussen die Calvinistiese groepering en die sogenaamde 'nasionaal-gereformeerdes', 'n verdere gebruik van die belydenisskrifte na vore gekom. Hierdie verdere gebruik was egter nie iets totaal nuut nie, maar het steeds in lyn gelê met wat Calvyn aan die hertog van Somerset as advies voorgehou het en waarvolgens die belydenisskrif ook kan dien as maatstaf waarmee die leer beoordeel word. Hierdie gedagte is versterk deur Calvyn se opvolger in Genéve, Theodorus Beza, wat op grond van Augustinus se siening in sy De doctrina Christiana, geargumenteer het dat die geloofsbelydenis in die vroeë kerk juis die funksie gehad het om tussen ortodoks en ketters te kan onderskei. Die argument was nou dat wie binne die norm van die belydenisskrif bly, bly ook binne die norm van die Skrif, omdat die belydenisskrif aan die Heilige Skrif genormeer is (Pont 1982:19).

Die posisie van die belydenisskrif het dus in die Calvinistiese kerke 'n bepaalde ontwikkeling deurgemaak. Dit is die konklusie waartoe Augustyn in sy navorsing gekom het en saam met Pont kan dit so opgesom word:

* Oorspronklik is die belydenisskrif ' $n$ verklaring van geloof, 'n verklaring van hoe die Heilige Skrif op bepaalde punte verstaan word. Op daardie stadium is die belydenisskrif vir die eie kring bedoel. 
* Dan word die belydenisskrif vollediger en meer teologies van aard. So word die belydenisskrif ' $n$ saambindende getuienis wat terselfdertyd ook gerig is op die medegelowiges en die buitestanders.

* Ten slotte word die belydenisskrif 'n middel om die kerk te beskerm teen kettery binne die kerk self. Dan word dit die duidelike omskrywing van die grense van die kerk. So word die belydenisskrif, ook as norm en reël van die prediking, die kort saamgevatte regula fidei.

Dit was dus die nood van die omstandighede of soos Pont dit stel, die sonde van die mens (Pont 1982:21), wat die kerk gedwing het tot die gebruik van die belydenisskrifte as beskermmiddele teen kettery. Die ondertekening van die belydenisskrifte het dus nou ook hierdie betekenis bygekry. Gou het dit egter geblyk dat die ondertekening van die belydenisskrifte sonder nadere bepaling nie genoeg was nie. In hierdie situasie het die verskillende formules ontstaan waarin presies bepaal is hoe die belydenisskrifte onderteken moes word. Na die klassis van Alkmaar wat die eerste was om dit op te stel en in te voer, het die provinsiale sinodes van Overijssel, Zeeland en Groningen gevolg, met die formule van die beroemde groot sinode van Dordrecht 1618-1619 as afsluiting (Bouwman 1934:566). Die betrokke formule lui in eie Arikaanse vertaling soos volg:

Ons, die ondergetekendes, dienaars van die Woord van God wat ressorteer onder die klassis NN verklaar eerlik en met 'n skoon gewete voor die Here met ons handtekening, dat ons van harte oortuig is en glo dat al die artikels en stukke van die leer wat in die Belydenis en Kategismus van die Nederlandse Gereformeerde kerke vervat is en van welke voornoemde leer sekere aspekte bowendien in die Sinode van Dordrecht in 1619 verklaar is, volkome met die Woord van God ooreenkom. Derhalwe beloof ons dat ons genoemde leer ywerig sal verkondig en bevorder, sonder om ooit iets teen hierdie leer, hetsy openlik of bedek, direk of indirek te verkondig of te skryf. Net so ook dat ons nie alleen elke dwaling wat met hierdie leer in stryd is en veral ook dié wat in die genoemde sinode veroordeel is, verwerp nie, maar dat ons ook van voorneme is om hulle te weerlê, teen te spreek en alles in die werk te stel om hulle uit die kerk te weer. En indien dit moontlik sou gebeur dat ons later enige prediking of geskrif sal aanbied, verkondig of verdedig; dat ons dit eer- 
stens aan die kerkraad, klassis of sinode bekend sal maak om daar getoets te word; dat ons bereid is om ons te eniger tyd gewillig aan die oordeel van die kerkraad, klassis of sinode te onderwerp, dat die straf, as ons hierteen sou handel, vanselfsprekend sal wees dat ons uit ons ampte gesuspendeer sal wees. En, indien die kerkraad, klassis of sinode, by nadenke te eniger tyd om gewigtige redes, terwille van die behoud van die eenheid en suiwerheid van die leer, dit nodig sou ag om van ons nadere verklaring van ons opvatting van enige artikel van hierdie Belydenis of van die Kategismus of van die uitsprake van die Nasionale Sinode te eis, so beloof ons ook hiermee dat ons op dieselfde straf as hierbo te alle tye daartoe gewillig en bereid sal wees. Egter met die behoud van reg tot appél indien ons beswaar sou hê teen die uitspraak van die kerkraad, klassis of sinode. Gedurende die tyd van appél sal ons met die oordeel en uitspraak van die provinsiale sinode tevrede wees.

(In die oorspronklike aangehaal deur Bouwman 1934:572)

Deur die belydenisskrifte op die wyse te onderteken, het die ondertekenaar dit geaktualiseer. Daarmee word dit daadwerklik sy eie belydenis en nie maar net ' $n$ historiese dokument waarvan die ondertekening 'n blote formaliteit was nie. Op die wyse verklaar hy vrywillig en sonder enige dwang dat die belydenisskrifte die norm en reël van sy prediking en sy dienswerk sal wees. Hier is geensins sprake van gewetensdwang of die beperking van teologiese ondersoek en studie nie, want die ondertekenaar verklaar immers 'eerlik en met 'n skoon gewete voor die Here' dat die belydenisskrifte 'volkome met die Woord van God ooreenkom'. Wat wel gebeur, is dat die ondertekenaar hom vrywillig kontraktueel aan die kerk verbind en sy woord gee dat hy saam met die kerk en soos die kerk sal bely. Daarmee gee hy ook die versekering dat sy prediking en dienswerk binne die grense van die leer, soos dit in die belydenisskrifte uitgedruk word, sal bly (Pont 1981:242).

Dit kan seker nie ontken word dat, vanweë die makliker hantering van die belydenisskrif as norm, die gevaar wel bestaan het dat die belydenisskrif verkeerdelik naas of selfs bo die Skrif gestel sou kon word nie. Die manier waarop die vergaderings van die ampte die belydenisskrifte sou hanteer in leertugsake, sou moes laat blyk of dit wel steeds slegs as norma normata gegeld het. Hoe die sinode van Dordt van 1618-1619 daaroor gedink het, blyk onder andere duidelik uit wat Arnoldus Thysius in 1625 daaroor geskryf het: 
De norm echter en de regel van deze handeling en van het Synodaal oordeel, moet geheel en al, alleen en onweersprekelijk zijn het woord van God in de Schrift vervat (Matt 2:5; Hand 15:14) welke ook door haar duidelikheid de Rechter genoemd kunnen worden (Joh 5:45) .... Niet echter geschriften en gezegden buiten deze, hoedanig ook, hetzij private, hetzij publieke, zijn norm of vorm der waarheid, maar slechts vorm van cordeel en overeenstemming der kerk.

(Thysius, in Pont 1982:21)

Hierby kan ook nog verwys word na Artikel 7 van die Nederlandse Geloofsbelydenis. Daaruit is dit reeds baie duidelik dat die Heilige Skrif steeds as die absolute norm gegeld het.

Dit het dus hoegenaamd nie beteken dat die belydenisskrifte van die kerk op die wyse onfeilbaar verklaar is en dus ook onveranderbaar nie. Die toetsingsreg het steeds gebly, maar dan moes by moontlike besware 'n bepaalde prosedure gevolg word. Die toetsinsreg het ingehou dat iemand wat beswaar gehad het teen enige artikel van enige belydenisskrif, dit by wyse van 'n gravamen kon voorlê vir beoordeling aan die bevoegde vergadering van die ampte (Bouwman 1912:188). In so 'n geval was die Skrif die enigste norm waarmee die beswaar of twyfel beoordeel is. Sou 'n predikant egter sondermeer die inhoud en waarheid van die belydenis in die openbaar aanval, dan het die belydenisskrif as die norm en die reël waarmee sy afwyking gemeet word, gegeld. Die argument hieragter was dat iemand wat deur sy handtekening of deur ' $n$ mondelinge belofte ingestem het dat die belydenisskrifte met Gods Woord ooreenkom, troubreuk en dus ook kontrakbreuk pleeg as hy hom nie aan die voorgeskrewe prosedure hou nie, maar dit in die openbaar aanval of verwerp. Trouens sodanige trouelose optrede bewys dat die dienaar ongeskik is vir sy dienswerk (Pont 1981:243).

Deur die gravamen word sowel die reg van die kerk om sy belydenis te handhaaf as die persoonlike vryheid erken en beskerm. Tereg sê Bouwman (1912:188) daarom: 'Ieder lid der kerk heeft recht, uit Gods Woord zijn meening op te maken, maar dan heeft ook de kerk de recht, deze meening te kennen vó6r iemand zijn gevoelen openbaar maakt, haar voordeel er mede te doen, of het te verwerpen, als zij bovindt, dat het met Gods Woord in strijd is'.

Behalwe die reg tot 'n gravamen, is daar nog in twee ander opsigte ruimte gelaat in verband met die belydenis, voordat enige leertugstappe toegepas is: 
Eerstens was daar die erkenning van die sogenaamde libertas prophetandi of die vryheid van profesie wat betrekking gehad het op die gebiede waaromtrent nie enige uitsprake in die belydenis gemaak is nie. By die uitleg van die Heilige Skrif kan sulke sake soos profesiee wat nog nie vervul is nie, chronologiese, topografiese, argitektoniese, genealogiese en ideologies-teologiese kwessies in aanmerking kom (Bouwman 1912:189).

Hierdie vryheid kon in ruim mate beoefen word mits daarvan nie misbruik gemaak word nie en steeds gehou is aan die regula fidei. Dit moet erken word dat grense hier moeilik aan te wys is.

Tweedens was daar die gedagte van toleransie. Dit het die bedoeling gehad om die swakkes en dwalendes tegemoet te kom. Hierdie gedagte het nie gespruit uit beginselloosheid nie, maar wou alleen rekening hou met die moontlikheid dat iemand deur gebrek aan insig, deur invloed van buite of deur vooringenomenheid, maar tog eerlik en opreg, besware kon hê teen een of meer stukke van die leer. Hierdie dwalinge hoef dan nie goedgekeur of gehandhaaf te word nie, maar kon verbeter word. Daar sou dus onderskei moes word of iemand vanweë 'n gebrek aan insig of uit onkunde gedwaal het en of hy bloot hardnekkig aan 'n bepaalde dwaallering vasgekleef het (Botha 1981b: 33).

\section{LEERTUG IN DIE NEDERLANDSE HERVORMDE KERK IN DIE NEGENTIENDE EEU}

Aanvanklik, en dan veral kort na die Sinode van Dordt 1618-1619, is leertug met noulettendheid gehandhaaf. Mettertyd is dit in die praktyk afgewater, hoewel dit nog in beginsel geleer is. Sedert die begin van die negentiende eeu het leertug in die Nederlandse Hervormde Kerk in praktyk feitlik verdwyn, hoewel nog aan die belydenisskrifte in die kerklike orde 'n plek toegeken is wat skynbaar nie met dié van die verlede verskil het nie. Dit was die gevolg van die verskuiwing in die denkbeelde van die Aufklärung wat nou 'n verskuiwing in die verstaan van die verhouding van Skrif en belydenisskrif in die orde en lewe van die kerk gebring het. So radikaal was die verskuiwing in die kerk ten opsigte van die belydenis dat prof Doedes in 1854 moes sê:

De Confusie komt in de plaats van de Confessie. Niet de afwijking van die belijdenis der Kerk, maar het ijveren voor de handhaving dier belijdenis wordt ketterij, en die het minst gunstig voor de leervrijheid en de met haar gepaarde ongebreidelde vrijzinnigheid gestemd zijn, moeten 
noodwendig voor de gevaarlijkste en meest zorgwekkende leden der gemeente gehouden worden.

(Doedes, in Rasker 1974:163)

Hierdie verskuiwing het die duidelikste gestalte gekry met die invoering van die 'Algemeen Reglement voor het bestuur der Hervorde kerk in het koninkrijk der Nederlanden in 1816'. In hierdie Algemeen Reglement, wat bedoel was om die Kerk van 'n behoorlike eenvormige kerkorde te voorsien en orde te bring waar daar chaos was, is die struktuur van die kerk losgemaak van die geloof en leer van die kerk. Die verbintenis tussen Skrif, belydenisskrif en kerkorde is verbreek en anders as in die Calvinistiese kerkordes het die Algemeen Reglement nie meer gefunksioneer as 'n weergawe van die ekklesiologie soos gevind in die Skrif as norma normans en die belydenisskrifte as norma normata nie. Die Algemeen Reglement was niks anders nie as 'n bestuurstruktuur wat uit die verenigingsdenke van die Aufkläring gebore is en wat van die kant van die owerheid, sonder dat die kerk noemenswaardig daarteen geprotesteer het of die krag geopenbaar het om ' $n$ alternatief te formuleer, aan die kerk opgelê is (Botha 1996:983).

Die halfheid, onbepaaldheid en gebrek aan geestelike krag wat die oorsake was dat toegelaat is dat die Nederlandse Hervormde kerk so 'n soort kerkorde gelate aanvaar het, word deur Fiolet (1953:12-13) teruggevoer na die feit dat die strydvaardige Calvinisme vanaf die tweede helfte van die sewentiende eeu geleidelik maar tog onafwendbaar die leiding in die kerk verloor het en 'n minderheidsparty geword het. Die gees van Erasmus, die groot Humanis van die sestiende eeu, soos voortgedra deur die Arminianisme, het langsamerhand nie alleen buite die kerk aan invloed gewen nie, maar stilweg ook die kerk binnegesluip en ook daar die oorhand gekry. Die gevolg van hierdie ontwikkeling was die ontstaan van botsende godsdienstige rigtings of kerklike modaliteite binne die Nederlandse Hervormde Kerk wat noodgedwonge almal geakkommodeer moes word omdat leertug nie meer moontlik was nie (Botha 1996:981-1000).

Die nuwe kerklike orde het ook 'n drasties nuwe proponentsondertekeningsformule meegebring. Die bestaande formule van Dordt is totaal gewysig en het veral een formulering bevat wat vir ' $n$ interpretasie in die rigting van leervryheid vatbaar was. So is dit ook later uitgelê en gaandeweg al verder in die rigting verander en dit het uiteraard die vestiging van die gedagte van leervryheid versterk. Die woorde waarna verwys word, was: '... dat wij de leer, welke overeenkomstig Gods Heilig Woord, in de aangenomen formulieren van enigheid ....' Hier het twee probleme na vore gekom: Eerstens het dit 'n vraag laat ontstaan oor die Dordtse Leerreëls wat nie oral deur die 
provinsiale sinodes aanvaar is nie. Tweedens, en dit was ernstiger van aard, het die vraag ontstaan of die 'overeenkomstig Gods Woord' quia (omdat) of quatenus (vir sover) verstaan moes word (Pont 1982:22). In 1841 het die Algemene Sinode uitspraak gegee dat die quatenus standpunt die enigste aanvaarbare kan wees. Verdere wysigings wat in 1854 aan die proponentsformule aangebring is, het dit net bevestig en in 1888 is die verwysing na die formuliere van eenheid totaal weggelaat.

In die negentiende eeu het in die Nederlandse Hervormde Kerk leervryheid oorgeneem en is die belydenisskrifte heeltemal op die agtergrond geskuif. Dit is wel waar dat steeds gestel is dat die Heilige Skrif die norm en die reël van geloof en lewe was. Tog was die saak nie so eenvoudig nie want, soos Pont dit stel, 'nadat die teoloë van die Groninger Rigting en die Moderne Teologie egter met die Skrif 'klaar' was, het daarvan nie meer veel oorgebly nie' (Pont 1982:23). In lyn met die gedagtes van die Aufklärung het die uitleg van die Skrif alleen en finaal by die indiwiduele predikant gelè. In so 'n situasie was daar eintlik geen norm meer nie. Bowendien het iemand soos Scholten verklaar dat die Bybel nie grondslag nie, maar slegs uitdrukking van die geloof van 'n Christen was (Scholten 1861:116).

$\mathrm{Na}$ ' $n$ lang en moeisame worsteling het die Nederlandse Hervormde Kerk in 1951 weer 'n kerkorde gekry wat tot 'n groot mate 'n terugkeer na die Calvinistiese presbiteriaal-sinodale vorm van kerkregering was (Rasker 1974:295). Hoewel daar groot verwagtinge gekoester is dat, na die aanvaar-ding en toepassing van die nuwe Kerkorde, en dan in die besonder onderafdeling 6 van artikel $X$ van die Kerkorde naamlik: 'De Kerk weert al wat haar belijden weerspreekt', die belydenis en die handhawing van die belydenis weer sy regmatige plek in die Nederlandse Hervormde Kerk sou verkry, het dit tot dusver blykbaar nog geen resultaat gelewer nie en bestaan die botsende modaliteite steeds onder een dak (Botha 1996:995-997).

\section{DIE BELYDENIS IN DIE KAAPSE KERK TOT 1837}

Vanaf 1652 tot 1804 het die gemeentes aan die Kaap organies en organisatories deel gevorm van die Nederlandse kerk. Die gemeentes het spesifiek onder die sorg van die klassis Amsterdam geval. Hoewel die Kaap nog tot in 1806 'n Nederlandse besitting was, was 1804 tog 'n afsluiting, omdat Kommissaris J A de Mist in die jaar sy Provisionele Kerken-Ordre uitgevaardig het, wat die moontlikheid vir die kerk aan die Kaap geskep het om kerkordelik selfstandig te kan ontwikkel (vgl Pont 1991:170-203). Hoewel dit om verskeie redes lank geduur het, het De Mist se Ordonnansie die weg gebaan dat die kerk aan die Kaap in 1824 'n eerste eie Algemene Kerkvergadering kon hou en ook by die geleentheid 'n eie kerklike orde of reglement of kerkwet kon opstel (Pont 1991:204-250). 
Merkwaardig genoeg is in die Algemeen Reglement voor het bestuur der Nederduitsche Herwormde Kerk in Zuid-Afrika nie spesifiek enige bepalings oor die belydenis of die belydenisskrifte van die kerk gemaak nie. Vreemd is dit egter tog ook weer nie, omdat die Algemeen Reglement van 1816 van die Nederlandse Kerk as voorbeeld en basis gegeld het. Omdat aanvanklik geen eie opleiding vir predikante bestaan het nie, is daar ook nie dadelik aan 'n ondertekeningsformule aandag gegee nie. In 1837 egter is ' $n$ formule wel opgestel met die oog op alle inkomende predikante. Die eerste paragraaf van hierdie formule wat tot in 1873 gegeld het, het soos volg gelui:

Wij, ondergeschrevenen, tot de openbare prediking in de Hervormde Kerk geadmitteerd, verklaren opregt en in goede gemoede voor den Heer, met deze onze naamtekening, dat wij van harte geloven, dat al de Artikelen en Stukken der Leer, in de Belijdenis en Catechismus, zijnde Formulieren van Eenigheid der Gereformeerde Kerken van Nederland, begrepen, met Gods Woord overeenkomen: Wij beloven voorzijde leer naarstig te zullen leren, en in onzen wandel getrouw te zullen handhaven, zonder iets tegen deselve leer, hetzij direct of indirect, te leeren of te schrijven.

(Aangehaal deur Engelbrecht 1953:213)

Verder het die Sinode van 1837 van die Kaapse kerk ook nog vasgestel: 'De Synode verklaart, dat de ondertekenaar van de Acte bij legitimatie door zijne onderteekening verklaart en te kennen geeft, dat hij de leer, die in de Formulieren van Eenigheid vervat is, gelooft overeenkomstig Gods heilig Woord te zijn (in Pont 1985:531). Die belydenisskrifte het in hierdie formule duidelik as regula fidei gefunksioneer (Pont 1981: 24). Hierdie formule is ook nog deur di Van der Hoff, Begemann en Smits onderteken voordat hulle na Transvaal is om predikant van die Nederduitsch Hervormde Kerk te word (Engelbrecht 1953:213). Na 1863 het die saak egter verander en het die predikante van die Nederduitsch Hervormde Kerk nie meer die betrokke formule onderteken nie, omdat die Nederduitsch Hervormde Kerk self sy predikante gelegitimeer het.

\section{DIE BELYDENIS IN DIE VROEË KERKWETTE VAN DIE NEDER- DUITSCH HERVORMDE KERK VAN AFRIKA}

Die Reglementen wor het Nederduitsch Hervormde Kerk in de Zuid-Afrikaansche Republiek van 1862 was die eerste amptelike Kerkwet van die kerk in die Zuid-Afrikaansche Republiek, alhoewel daar reeds in 1857 'n konsep Reglement opgestel is 
(Botha 1963:25). Reeds in artikel 9 van die betrokke konsep kom wel na vore hoe in die kerk oor die verhouding Skrif en belydenisskrif gedink is. In die artikel is naamlik gestel: 'Beschuldigingen tegen de leer van een Predikant, zullen inhouden duidelijke bewijzen dat hij de leer, welke volgens Gods heilig Woord, vervat is in de aangenomen formulieren van eenigheid der Gereformeerde Kerk, heeft wedersproken of bestreden' (in Pont 1981:25).

Dit kom daarop neer dat die regula fidei in die belydenisskrifte geformuleer is en dat die bepaalde formulering wel in ooreenstemming is met die Woord van God soos in die Skrif vervat. Op die wyse is die belydenisskrifte dan die norma normata en kan afwykings ook daaraan gemeet word. In aansluiting by hierdie opvattings is in 1866 ook 'n eie proponentsondertekeningsformule opgestel wat tot op die huidige oomblik nog onveranderd in die Nederduitsch Hervormde Kerk van krag is. Die formule lui:

Ek/Ons, die ondergetekende(s), dienaar(s) van die Woord van God in die Nederduitsch Hervormde Kerk van Afrika, verklaar hiermee dat ek/ons die leer wat uitgedruk is in die formuliere van eenheid, naamlik die Nederlandse Geloofsbelydenis, die Heidelbergse Kategismus en die Dordtse Leerreëls, en wat in ooreenstemming is met die Woord van God, van harte onderskryf en getrou sal verkondig. Ek/Ons beloof verder om my/ons stiptelik te hou aan die orde wat neergelê is in die Wet en Bepalings van die Kerk en by oortreding daarvan my/ons te onderwerp aan die oordeel van die bevoegde kerklike vergaderings. Deur hierdie formule te onderteken, verklaar ek/ons dat ek/ons vas oortuig is en glo dat die leer wat in die formuliere van eenheid uitgedruk is, in volkome ooreenstemming met die Woord van God is.

In hierdie formule kom tot uitdrukking dat die Nederduitsch Hervormde Kerk steeds hoë waardering het vir die eerbiedwaardige belydenisskrifte van die sestiende eeu en deur te vereis dat dit steeds by toelating onderteken moet word, verwag die kerk dat die ondertekenaar dit vir homself en vir die kwaliteit van sy werk volkome ter sake en eietyds maak (Pont 1982:3). Die belydenisskrifte is dus ook hier as regula fidei gesien. Soms het dit selfs in die vroeë kerkwette voorgekom of daar 'n gelykstelling van Skrif en belydenisskrif was. So is in artikel 1 van die Algemene Bepalingen van die Kerkwet van 1869 ten opsigte van die belydenis gestel:

Hare belijdenis staat uitgedrukt in de volgende formule, de Nederduitsch Hervormde Kerk in de Zuid-Afrikaansche Republiek grond zig op de leer van de Bijbel, als Gods heilig Woord; den Heidelbergschen cate- 
chismus; de 37 Artikelen der Nederlandsche geloofsbelydenis en de 5 Dordtse leerregels, zooals die zijn vastgesteld in 1618 en 1619 te Dordrecht.

Dit moet toegegee word dat hierdie formulering lomp was en dat hieruit inderdaad wel die afleiding gemaak kon word dat die belydenisskrifte gelyk gestel word met die Skrif. Dit is reeds in 1888 deur ds $\mathbf{M} \mathbf{J}$ Goddefroy aangetoon en daarom wou hy die artikel laat wysig. Sy argument was:

Vooreerst is dit minder juist om te zeggen 'dat de belijdenis der Kerk in een formule staat uitgedrukt', terwijl deze belijdenis toch eigenlijk alleen hare uitdrukking vindt in de Formulieren van Eenigheid der Ned Herv Kerk; ten andere is het niet aanbevelenswaardig te zeggen: de kerk grond zich op de leer van den Bijbel, den Heidelbergschen Cathechismus, de 37 Artikelen en de vijf Dordtse leerregels, omdat zoodanige formulering aanleiding geeft om te denken aan gelijkstelling van Gods Woord met menschelijke Schriften, door ze als in een adem te noemen, en op een lijn te stellen als grondslag der Kerk, hetgeen strijdig is met het Ned Hervormde grondbeginsel neergelegd in Art 7 van de Ned Geloofsbelijdenis.

(Notule van die Algemene Kerkvergadering 1888:56)

Daarom wou Goddefroy die artikel wysig om soos volg te lui: 'Hare belijdenis grondt zich op de Heilige Schriften als Gods Woord en staat uitgedrukt in de formulieren van eenigheid, zooals die zijn vastgesteld in 1618 en 1619 door de Nationale Sinode te Dordrecht' (Botha 1981a:66).

Hoewel Goddefroy se voorstel tot wysiging aanvaar is, het dit nie wet geword nie, omdat uiteindelik besluit is om die Kerkwet van 1869 onveranderd te laat. Die rede hiervoor was die onrus by die Algemene Kerkvergadering dat veranderinge aan die Kerkwet op daardie stadium, die saak rondom herwinning van die kerklike eiendomme, wat na die mislukte kerkvereniging van 1885 in die hande van die verenigde kerk gekom het, sou benadeel (Vgl Botha 1981a:65).

\section{DS GODDEFROY VERWOORD DIE KERK SE STANDPUNT}

Uit sy argumente en voorstel was dit baie duidelik dat Goddefroy 'n helder siening gehad het ten opsigte van die funksie van die belydenisskrifte in die kerklike orde. Nie alleen het latere kerkwette in die rigting beweeg wat hy aangedui het nie, maar by 
verskillende geleenthede het hy as leidinggewende figuur en woordvoerder die standpunt van die Nederduitsch Hervormde Kerk verwoord. Ongetwyfeld het hy daardeur ook ' $n$ belangrike bydrae gelewer om die Calvinisties-reformatoriese tradisie ten opsigte van die funksie van die belydenis in kerkregtelike verband in die Nederduitsch Hervormde Kerk te bewaar en te bestendig. Dit het veral gebeur in sy optredes in woord en geskrif teenoor die aanvalle van ds H S Bosman op hom en die Nederduitsch Hervormde Kerk in 1890 en in die Ruysch van Dugteren-saak van 1911. Omdat beide hierdie gevalle reeds meerdere male uitvoerig behandel is (Botha 1981a:82-92, 200209; Botha 1981b:1-28; Botha 1982:30-44; Botha 1977:41-57; Pont 1985:519-546) word hier volstaan met enkele opmerkings.

Waar Bosman die Nederduitsch Hervormde Kerk en Goddefroy van buite aangeval en van leervryheid en van geringskatting van die belydenisskrifte beskuldig het, daar het ds Ruysch van Dugteren die kerk van binne beskuldig van leerdwang en van oorskatting van die betekenis van die belydenis. Teenoor Bosman se aanvalle en beskuldigings het Goddefroy volledig geantwoord in 'n geskrif met die titel De kerkkwestie niet een leer-maar een levenskwestie. Goddefroy het baie duidelik aangetoon dat Bosman se opvatting daarop neerkom dat die belydenisskrifte naas en selfs bo die Skrif gestel word. Dit was totaal onaanvaarbaar vir die Nederduitsch Hervormde Kerk en vir hom as predikant van dié kerk. Maar dit het geensins beteken dat die gesag van die belydenis nie erken en gehoorsaam moes word nie. Hy het daarop aangedring dat die predikant hom moes hou aan wat hy beloof het toe hy die ondertekeningsformule quia onderteken het. Die belydeniskrifte het dus beslis vir Goddefroy en die Nederduitsch Hervormde Kerk bindende gesag gehad as die norm van die prediking en norm en reël vir die leer en lewe in die kerk. Daarom dat hy ook enige voorwaardelike of quatenusondertekening van die belydenisskrifte ten enemale verwerp het (Botha 1981a:87).

Ook in die geval van die Van Dugteren-saak het Goddefroy in 'n geskrif aanvalle op die Nederduitsch Hervormde Kerk beantwoord. In 'n geskrif waarvan die titel Schorsing van Ds Ruysch van Dugteren: Word de Hervormde Kerk Rooms? duidelik stel waarvan die Kerk verdink en beskuldig word, het dr H D J Bodenstein, 'n lidmaat van die Nederduitsch Hervormde Gemeente Pretoria, verantwoording geëis van die Kommissie van die Algemene Kerkvergadering oor die optrede teen ds Van Dugteren. In 'n geskrif getitel Neen! Niet Rooms! antwoord Goddefroy en gee hy 'n volledige siening van die funksie van die belydenis in kerkregtelike verband binne die Nederduitsch Hervormde Kerk.

Slegs 'n drietal argumente van Goddefroy word hier kortliks genoem. Eerstens betoog hy dat Van Dugteren homself buite die bediening van die Woord in die Nederduitsch Hervormde Kerk geplaas het omdat hy sy handtekening onder die ondertekeningsformule terugetrek het. Daarmee het hy sy kontraktuele binding met die kerk om die kerklike belydenisskrifte en wette te aanvaar en te gehoorsaam verbreek. Godde- 
froy beroep hom op Dordt en betoog dat, hoewel die predikante in die Nederduitsch Hervormde Kerk nie in soveel woorde dieselfde ondertekeningsformule onderteken het nie, die beginsel steeds dié van Dordt is. Daarom kon nie toegelaat word dat die predikant oor die belydenis van die Kerk tegelyk ja en nee sê nie en dat hy die toetsingsreg sondermeer en slegs in eie hand sou neem en dan teen sy eie onderneming teenoor die kerk handel nie. Om sy standpunt nader te motiveer, verwys Goddefroy na artikel 53 van die post-acta van die Sinode van Dordt: '... dat menschen die b.v. het toetsingsrecht van de kerk, in eigen handen zouden willen nemen, zich zelf moeten verbinden, om indien zij tegen hun handtekening machten handelen, door de eigen daad (ipso facto) gesuspendeerd zouden zijn van hunne diensten'.

Tweedens toon Goddefroy aan wat die verskil tussen die Roomse en Protestantse kerke oor die funksie van die belydenisskrifte is. By Rome is die pous, as opvolger van Petrus en plaasvervanger van Christus, die een wat in geloofs- en gewetensake eenvoudig gebied en sy uitsprake moet eenvoudig as onfeilbaar aanvaar word. Daar is sprake van gewetensdwang.

By die Protestante is die Woord van God die enigste rigsnoer in sake van geloof en lewe. Menslike gesag kan nie die gewete dwing nie. Daarom is die belydenisskrifte in die Protestantse kerke altyd toetsbaar aan die Skrif alleen. Maar dit beteken nie dat die belydenis in Protestantse kring so gerelativeer is dat elke lidmaat en elke predikant dit na willekeur kon uitlê nie. Daarom kan die toetsingsreg nie maar ordeloos geskied nie, maar bestaan daaromtrent bepaalde voorskrifte. Ook in Protestantse kring is geloofseenheid verlang en daarom het die eis gegeld: 'Onderwerping aan de Belijdenis der Kerk omdat zij Bijbelsch, onderwerping aan de Bijbel omdat deze goddelijk is'. Die toetsingsreg mag onder geen omstandighede met 'teugelloze vrijheid' verwar word nie. Voortvloeiend hieruit betoog Goddefroy dan derdens dat elke lidmaat en predikant gebonde is aan sy eie belydenis en belofte. Goddefroy stel dit so:

Tegenover 'Kerkgezag en gewetensdwang' van Rome stellen de kerken der Hervorming 'gebondenheid aan eigen belijdenis en belofte'. Is dit zoo onredelijk? Waar Rome gezag uitoefend over de gewetens der menschen; haar Belijdenis van boven af oplegd en decreteert; en de belijdenis desnoods te vuur en te zwaard op de keel drukt harer leden! daar vraagt de Hervormde Kerk niets anders (niets meer, maar ook niets minder!) dan eerlijke uitvoering van eigen belofte en kontrakt, gemaakt ten aanzien van de uitdrukking van de geloof der gemeenschap, neergelegd in de Formulieren; opgemaakt door de wettige daartoe verkozen vertegenwoordigers der gemeente. 
Hierdie argument van Goddefroy veronderstel absolute eerlikheid by die ondertekening van die ondertekeningsformule. Wie teken maak die belydenis van die kerk sy eie belydenis wat hy van harte wil bely. Wie nie van harte (=quia) kan teken nie, durf nie teken nie. Want 'n voorwaardelike (=quatenus) ondertekening is eenvoudig onsin. Dit is net so goed as om nie te teken nie. Wie egter geteken het durf nooit met die belydenis na willekeur omgaan met die houding: '... ik zal deze in de Kerk; van den Kansel en overal waar het mij behaagt behandelen, verklaren en uitleggen, naar eigen

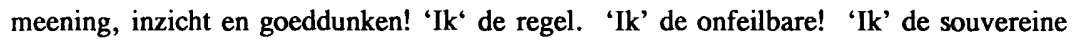
Macht! ... Dat nooit!'

Wie eerlik, vrywillig en van harte geteken het, is gebonde en verplig om by sy eie belofte en belydenis te bly. Alleen so kan die kerk gebou word.

Met hierdie argumente was Goddefroy self getrou aan die standpunt wat hy by sy aankoms in die Zuid-Afrikaansche Republiek ingeneem het, naamlik: 'Geen Christendom zonder Christus; geen kerk zonder belijdenis; maar ook geen belijdenisschrift of formulier boven of nevens het onbedriegelijke Woord des Heeren'. Onder andere kan hieruit afgelei word dat hier ' $n$ deurwinterde teoloog aan die woord is, wat aan die een kant enige beskuldiging van teologiese modernisme teen hom afsny, maar terseldertyd ook duidelik laat blyk dat dit nie beteken het dat hy die belydenisskrifte daardeur naas of bokant die Heilige Skrif stel nie. Goddefroy het hier op 'n baie duidelike wyse die opvatting en tradisie van die Nederduitsch Hervormde Kerk oor die saak verwoord en dit daarmee ook verder help bestendig.

\section{DIE BELYDENIS IN DIE KERKWET EN BEPALINGS VANAF 1951}

Hier word volstaan met enkele opmerkings:

* Die Kerkwet van 1951 het groter ruimte gebied dat die bepalende lyn in die kerkregtelike agtergrond van die Kerk, naamlik die presbiteriaal-sinodale lyn, sterker uitgebou kon word (Pont 9181:5).

* Basies egter het die Nederduisch Hervormde Kerk se beskouing oor die plek, die funksie en die handhawing van die belydenis nie wesenlik verander van wat dit tot in 1950 was nie. Wat wel gebeur het, is dat die bekouing duideliker en beter verwoord is. Word Artikel I van die Wet (1995) byvoorbeeld vergelyk met dieselfde Artikel van voor 1950, blyk dit duidelik. In Artikel XI word verder uitvoerig gehandel daaroor dat die kerk daadwerklik 'n belydende kerk wil wees wat ook in gemeenskap met die vadere sy geloof in die Drie-enige God wil bely. 
* Uit Artikel I en XI blyk ook dat steeds daaraan vasgehou word dat die kerk se belydenis in die drie ekumeniese belydenisse en die drie formuliere van eenheid vervat of uitgedruk word.

* Kragtens Artikel XI.3 bely die kerk in sy totale doen en late elke keer weer Jesus Christus as Hoof van die kerk en as Heer van die wêreld.

* Die kerk het in Artikel XI.4 dit duidelik verwoord dat hy sy belydenis wil handhaaf deur alles wat dit weerspreek uit sy midde te weer. Anders gestel: die kerk sou geen leervryheid toelaat nie.

* Soos in die verlede moes elkeen wat toegelaat wil word tot die dienswerk van dienaar van die Woord, by sy toelating 'n onderneming gee wat hy met sy handtekening moes bekragtig ten opsigte van die leer of belydenis van die kerk (Wet en Bepalings 1992, Bepaling 73).

* Ruimte is geskep en prosedures voorgeskryf is in geval waar daar besware teen die belydenis na vore sou kom (Wet en Bepalings 1992:Bepaling 75). Leerdwang was nie in die gedagte van die kerk nie.

* Uitvoerige bepalings ten opsigte van opsig en tug, wat ook leertug insluit, is daargestel (Wet en Bepalings 1992:Bepaling 99 tot 128).

\section{DIE SAAK TEEN PROF AS GEYSER 1961-1962}

Uiteraard kan nie volledig op die saak ingegaan word nie. Slegs enkele relevante aspekte waaruit beskouings oor die leer en leertug in die Kerk en prosedures wat gevolg is, na vore kom, word genoem. Prof Geyser is in 1961 deur drie studente van dwaalleer aangekla by die Kommissie van die Algemene Kerkvergadering en die versoek was dat die belydenis genoem na Atanasius as norm sou geld (Pont 1985:540).

Die ondersoek het min of meer vier maande in beslag geneem. Die Kommissie het onder die diepe besef van die erns van die saak en in lyn met die tradisie van die Nederduitsch Hervormde Kerk, dat nóg leerdwang nóg leervryheid vir die kerk aanvaarbaar was, die ondersoek hanteer. Van. die Vergadering van Professore het die Kommissie 'n pre-advies gevra oor 'n hele reeks sake wat ook wyer as die klag gehandel het, met die bedoeling om self groot helderheid oor die beoordelingsnorm te kan hê. 'n Uiters belangrike aspek van die pre-advies was die duidelike implikasie '... dat nie nèt na die belydenisskrifte geluister kan word nie, maar óok na die Heilige Skrif as 
die regula fidei' (Pont 1985:541). Uit sy Bevinding blyk dat die Kommissie nie nèt op die uitsprake van die belydenisskrifte gelet het nie, maar die saak baie wyer ondersoek, bedink en beredeneer het. Waar die Kommissie wel die belydenisskrifte as norm hanteer het, is dit baie duidelik dat die Kommissie 'dié norm voóraf aan die Skrif self, as regula fidei, getoets het' (Pont 1985:544).

Die Kommissie het verklaar dat daar wel vryheid vir die eksegese bestaan, maar dit mag nie verstaan word as vryheid sondermeer vir die individuele eksegeet nie. Daarmee sou die kerk homself kon uitlewer aan die gevaar van subjektiwistiese eksegese. Die agtergrond vir hierdie gedeelte van die uitspraak van die Kommissie, het die Kommissie self so verwoord:

Verneem die Skrifondersoeker die Woord van God anders (as in die belydenisskrif), is die Kerk bereid om na hierdie Skrifondersoeker te luister op 'n wyse waarvoor die Kerk duidelike riglyne neergelê het. Intussen is sodanige Skrifondersoeker nie belet om die Woord van God so te verneem soos hy dit verneem het nie; alleen is hy nie toegelaat om sy individuele verneem van die Woord van God te stel bókant of selfs teenór die verneem van daardie selfde Woord deur die Kerk nie.

(aangehaal deur Pont 1985:542)

Konkluderend kan gesê word dat die betrokke leertugsaak deur die bevoegde vergadering hanteer is op so 'n wyse dat die beproefde standpunt van die kerk tot sy reg gekom het. Die kerkordelike reëlings, soos dit in die Wet en Bepalings neergelê is, het hiertoe wel 'n bydrae gelewer.

\section{DIE KONSEP KERKORDE VAN 1997}

Daar moet in gedagte gehou word wat die status van die konsep Kerkorde (hierna slegs Konsep genoem) is. Die Konsep het eers 'n regsgeldige Kerkorde geword nadat dit deur die buitengewone sitting van die vier en sestigste Algemene Kerkvergadering bespreek, gewysig, goedgekeur en in werking gestel is. Daar kan dus geargumenteer word dat die Ordereëls en Ordinansies in verband met die belydenis en belydenisskrifte, slegs die voorstelle is van die opstellers van die Konsep. Tog kan ook gesê word dat die finale Konsep nie maar net die produk is van die Komitee vir die herskrywing van die Kerkwet nie. Kommentaar wat vooraf van kerkrade, ringsvergaderings en indiwidue ontvang is, is ook in aanmerking geneem. Terwille van die duidelikheid rondom 
begrippe, moet daarop gelet word dat voorgestel word dat die oorkoepelende Kerkwet en Bepalings, en die onderskeidende Wet en Bepalings, onderskeidelik vervang word met Kerkorde, Ordereëls en Ordinansies.

Dit kan nie hier gaan om die beredenering en motivering van elke Ordereël en die plasing daarvan nie, ook nie oor die meer prominente plasing van die belydenis nie. In die Konsep word naamlik reeds in Ordereël 1 oor belydenis gehandel, terwyl dit in die bestaande Kerkwet eers in Artikel XI aan die orde kom. Hieruit moet nie afgelei word dat daar ' $n$ veranderde opvatting oor die plek en die funksie van die belydenis in die kerk gekom het nie.

Wat wel interessant is, is dat, anders as in die res van die Kerkorde, in Ordereël 1 van die eerste persoon (meervoud) gebruik gemaak word (vgl Konsep 1997:1). Hier kan wel die afleiding gemaak word dat die tradisionele opvatting beklemtoon word dat dit vir die kerk in die belydenis gaan om 'n eksistensiële lewenswaarheid, 'n waarheid wat geglo en daadwerklik bely moet word. Dit is antwoord op die Woord van God. Die kerk besit nie die belydenis as 'n objektiewe gegewene, as iets wat teenoor die kerk staan nie, maar dit is die eie antwoord op die Woord. Die kerk wil daarmee sê dat hy belydende kerk is '... wat die verpligting aanvaar om sy belydenis uit te spreek en wie se bestaan in die wêreld deur sy belydenis bepaal word' (Pont 1985:524).

Soos in die verlede word ook hier baie duidelik gestel dat die kerk sy geloof in gemeenskap met die kerk van alle eeue bely en dat sy belydenis verwoord is in die drie ekumeniese belydenisse en in die drie formuliere van eenheid (Ordereël 1).

In Ordereël 1.1 word uitgespel wat die funksie van die belydenis is. In die geval word die begrip leer as alternatief vir belydenis gebruik:

1.1 Die leer van die Kerk soos verwoord in die belydenisskrifte geld vir ons as

1.1.1 samevatting van die wesenlike van die geloof

1.1.2 norm vir die verkondiging

1.1.3 basis van die kerklike onderrig

1.1.4 maatstaf vir teologiese onderrig en uitsprake

1.1.5 rigsnoer vir kerklik-teologiese uitsprake.

(Konsep 1997:1)

Hierdie formulering bevat nie nuwe gedagtes nie, maar is 'n poging om die bestaande en bekende gedagtes helderder en duideliker te verwoord. Die belydenis soos in die belydenisse en belydenisskrifte verwoord, word as 'n samevattende regula fidei, as 'n 
genormeerde regula fidei hanteer. In die Konsep word die handhawing van die belydenis nie negatief begrond as net maar die afweer uit sy midde van alles wat die belydenis weerspreek nie, maar dit word positief soos volg gestel: 1.2 . Die handhawing van ons belydenis; 1.2.1 dien die eenheid van die Kerk; 1.2.2 spoor die gemeente aan tot 'n loflied oor die rykdom van die heil in Christus.

Oor die dat van die handhawing van die belydenis bestaan daar geen twyfel nie, dit moet gedoen word. Leervryheid is dus nie in die gedagte van die Konsep nie. In Ordinansie 1 word dan nader uitgespel hoe die Kerk die belydenis handhaaf. Dit word gedoen deur voorskrifte wat onder vier subhoofde tuisgebring word:

\section{* Kerk se binding aan die belydenis (Ordinansie 1.1)}

In die eerste plek word hier duidelik gestel dat alle lidmate aan die belydenis van die Kerk gebonde is (1.1.1). Soos in die verlede, word van die kandidate vir die amp van dienaar van die Woord 'n spesifieke onderneming, wat met sy handtekening bekragtig is, vereis. ' $n$ letwat gewysigde formule word in Ordinansie 1.1.2 voorgestel naamlik: 'Ek verklaar hiermee dat ek die leer wat uitgedruk is in die formuliere van eenheid, naamlik die Nederlandse Geloofsbelydenis, die Heidelbergse Kategismus en die Dordtse Leerreëls van harte onderskryf en dat ek vas oortuig is daarvan en glo dat dit in ooreenstemming is met die Woord van God. Ek beloof om my in my verkondiging deur hierdie leer te laat lei en om my te hou aan die orde wat neergelê is in die Kerkorde van die Nederduitsch Hervormde Kerk van Afrika. By oortreding daarvan sal ek my onderwerp aan die oordeel van die bevoegde kerklike vergaderings'.

Wesenlike verskil met die bestaande formule soos in Bepaling 73 van die Wet en Bepalings opgeteken, is daar nie. Daar lê agter die formule die verwagting dat die kandidaat die belydenis ' $n$ eie en eietydse belydenis sal maak en dit doen hy dan as hy daarmee instem deur dit met sy handtekening te bekragtig. Dat slegs 'n quiaondertekening moontlik is, blyk wel uit die formulering: '... dat ek die leer ... van harte onderskryf en dat ek vas cortuig is daarvan en glo dat dit in ooreenstemming is met die Woord van God'. Wie so bely kan seker nie sê dat hy daartoe gedwing word nie. As hy bowendien ook bereid is om die belofte, om hom in sy prediking deur hierdie leer te laat lei te onderneem, dan kan die Kerk seker verwag dat hy trou sal wees aan eie belydenis en belofte. 
As in Ordinansie 1.1.3 bepaal word: 'Opsighoudende vergaderings handel volgens die kerklike dissipline met ampsdraers wat nie aan die belydenis getrou bly nie', het dit sekerlik die bedoeling dat leervryheid nie toegelaat sal word nie, of anders gestel, dat leertug wel toegepas moet word. Dat hier net na optrede teen ampsdraers verwys word, sluit nie uit dat teen lidmate wat aan die belydenis ontrou is, opgetree sal word nie. Ordereël 8.2 bepaal uitdruklik dat ook lidmate aan die dissipline onderworpe is en onder die Werkopdrag van die ouderlingevergadering word in Ordinansie 3.1.2( $\mathrm{x}$ ) bepaal: 'vermaan die onordelikes, tug diegene wat in 'n valse leer of ' $n$ aanstootlike lewe volhard, ....'

* Beswaar teen kerklike leerbeslissings (Ordinansie 1.2)

Die aangeleentheid van die sogenaamde gravamen word in die bestaande Kerkwet en Bepalings in Bepaling 75 hanteer. In die opskrif word gepraat van Besware teen die belydenis, terwyl in Bepaling 75.1 weer sprake is van belydenissuitsprake van kerklike vergaderings. Besonder duidelik is dit nie. In die Konsep word gepoog om die saak duideliker uiteen te sit deur dit onder twee afsonderlike hoofde tuis te bring naamlik Beswaar teen kerklike leerbeslissings, Verandering aan belydenisskrifte en deur ' $n$ derde moontlikheid by te voeg naamlik Ander of nuwe belydenisskrifte.

* Besware teen enige leerbeslissings van die Algemene Kerkvergadering word volgens 'n voorgeskrewe prosedure hanteer. Onrusskeppende of opruiende verdagmaking teen enige leerstuk of aspek van die belydenis wat onrus en verwarring in die Kerk kan veroorsaak, word uitgesluit. By voorlegging van die besware aan die Algemene Kerkvergadering, is die beslissing van die Vergadering bindend. Met diegene wat die beslissing nie aanvaar nie, of wat nie die voorgeskrewe prosedure volg nie, word onder die dissipline gehandel.

* In beide Ordinansie 1.1 en 1.2 is daar sprake van optrede onder die dissipline. Met die oog op die dissipline, wat onderskei word in opsig en tug, word uitvoerige bepalings gevind in Ordereël 8 en in Ordinansie 8. Ook hier gaan dit nie om 'n summiere proses wat rigied afgehandel moet word nie. Daar word voldoende tyd en geleentheid aan alle betrokkenes voorsien vir voorbereiding, beredenering en afhandeling van hulle onderskeie sake. Verder word ook nog genoegsame geleentheid vir appél voorsien (vgl Ordinansie 8.3.8). 
* Verandering aan belydenisskrifte (Ordinansie 1.3)

Die moontlikheid word voorsien en die prosedure voorgeskryf om enige belydenisskrif te verander. Om van $\mathrm{krag}$ te word, moet veranderinge deur die Algemene Kerkvergadering met algemene instemming aanvaar word.

* Ander of nuwe belydenisskrifte (Ordinansie 1.4)

Ook hierdie moontlikheid word voorsien. Dieselfde prosedure as in 1.3 word voorgeskryf.

In Ordinansie 1.2, $1.3 \& 1.4$ word die moontlikheid geskep om ander Reformatoriese kerke te raadpleeg, om advies te vra of minstens in kennis te stel rondom die bepaalde aangeleenthede, rakende die belydenis.

\section{TEN SLOTTE}

Die Nederduitsch Hervormde Kerk wil 'n Christusbelydende kerk wees wat in die woorde van die aanvaarde belydenis sy geloof wil bely en nie maar net daarop wil roem dat hy ' $n$ suiwere leer en 'n regsgeldige belydenis het nie. Hierdie belydenis is uitgedruk of vervat in die belydenisskrifte van die Kerk en juis daarom verwag die Kerk van sy lidmate en ampsdraers om met verantwoordelikheid en respek met die belydenisskrifte om te gaan. Dit blyk uit die kerkordelike reëlings en uit die geskiedenis van die kerk sedert sy vestiging in Transvaal vanaf 1842.

Bewus daarvan dat die belydenisskrifte mensewerk is, het die Nederduitsch Hervormde Kerk nog altyd rekening gehou met die moontlikheid dat daar besware op grond van die Skrif teen die belydenisskrifte ingebring kon word wat op veranderinge aan die belydenisskrifte kon uitloop. Ook daarmee is in die kerkordelike reëlings rekening gehou. Terselfdertyd het die kerk hoë waardering vir die belydenisskrifte gekoester juis omdat die kerk se belydenis daarin vervat is. Dus het die kerk ook nie leervryheid toegelaat nie. Aan die ander kant het ketterjagtery nog nooit in die kerk voorgekom nie.

\section{Literatuurverwysings}

Augustyn, C 1969. Kerk en belijdenis. Kampen: JH Kok.

Berkouwer, G C 1972. Dogmatische Studiën: De Kerk, II. Kampen: JH Kok.

Botha, S J 1981a. Ds Marié Joseph Goddefroy 1848-1920: Sy lewe en betekenis. Pretoria: HAUM.

1963. Die historiese agtergrond van die Kerkwet van 1863 . HTS $19 / 1$ \& 2, 25-36. 
Botha, S J 1981b, Die Nederduitsch Hervormde Kerk en leervryheid uit die geskiedenis van die Nederduitsch Hervormde Gemeente Pretoria. HTS 37/3, 1-28.

- 1981b. Die belydenis in kerkregtelike verband. HTS 38/2 \& 3, 30-44.

1993. Die heil, gehoorsaamheid, struktuur en kerkreg. Publikasie van die Universiteit van Pretoria. (Nuwe Reeks 285.)

1996. Modaliteite in die Nederduitsch Hervormde Kerk van Afrika? HTS 52/4, 1981-1000.

Bouwman, H 1912. De kerkelijke tucht. Kampen: J H Kok

H 1934. Gereformeerd Kerkrecht, II. Kampen: JH Kok.

Calvinus, J 1559. Institutio Christianae Religionis.

Coertzen, P 1991. Gepas en Ordelik. Pretoria: RGN

De Greef, W 1989. Johannes Calvijn: Zijn werk en geschriften. Kampen: De Groot Goudriaan.

De Wet, J I 1973. Is 'n nuwe belydenis moontlik en nodig? Jaarblad van die Van Der Hoff Teologiese Vereniging.

Engelbrechet, S P 1953. Geskiedenis van die Nederduitsch Hervormde Kerk van Afrika. Kaapstad-Pretoria: HAUM-JH De Bussy.

Fiolet, A 1953. Een kerk in onrust om haar belijdenis. Tweede druk. Nijkerk: GF Callenbach NV.

Goddefroy, M J 1890. De kerkkwestie niet een leer- maar een levenskwestie. Den Haag.

Hovius, J 1968. Het toezicht op de dienaren des Woords door de kerkelijke vergaderingen. Vlaardingen.

Kerkwet en Bepalings van die Nederduitsch Hervormde Kerk van Afrika 1992.

Konsep Kerkorde van die Nederduitsch Hervormde Kerk van Afrika 1997.

Plomp, J 1969. De Kerkelijke tucht bij Calvijn: Kampen: JH Kok.

Pont, A D 1981. Die historiese agtergronde van ons kerklike reg, Deel 1. PretoriaKaapstad: Haum.

— 1982. Die belydenis in historiese verband. HTS 38/2 \& 3, 1-29.

1985. Die funksie van die belydenis en die dogma in die struktuur van die

Nederduitsch Hervormde Kerk en die implikasies daarvan vir die predikant. HTS 41/4, 519-546.

1991. Die historiese agtergrond van ons kerklike reg, Deel 2. Pretoria: Kital. Rasker, A J 1974. De Nederlandse Hervormde Kerk vanaf 1795. Kampen: JH Kok. Scholten, J H 1861. De leer der Hervormde Kerk, Deel 1. Leiden.

Van Wyk, B J 1991. Die presbiteriaal-sinodale kerkbegrip. Pretoria: Kital.

Van Ruler, A A 1973. Hoe functioneerde de belijdenis? in Theologisch Werk, Deel VI.

Nijkerk: GF Callenbach. 
Velthuysen, G C 1985. Die funksie van die belydenis in die struktuur van die kerk en die betekenis daarvan vir die predikant. HTS 41/3, 372-377. 